\title{
FINGER-PRINT PATTERNS IN CONGENITAL HEART DISEASE
}

\author{
BY \\ A. SÁNCHEZ CASCOS \\ From the Departments of Cardiology and Genetics, Institute for Medical Research, Fundacion Jiménez Diaz, \\ Madrid, Spain
}

Received January 20, 1964

The problem of the ætiology of congenital heart disease has lately been attracting increasing attention. Most studies, to date, have dealt with family histories, and the results of these suggest that recessive inheritance may account for a significant number of cases. The demonstration of an association between individual types of congenital heart disease and somatic hereditary traits could be of value both in the ascertainment of the genetic causation of the condition and perhaps in the diagnosis of the anomaly. Dermatoglyphs (finger-prints) are an example of such a somatic hereditary trait; and these prints have recently proved of great interest in the study of chromosome aberrations (Penrose, 1963).

This paper reports briefly our preliminary observations of the finger-print patterns from 150 patients with congenital heart disease as compared with those from 50 control subjects: it is planned to report on the palm print subsequently. Although the number of patients so far studied is rather small, some interesting findings have already emerged. In some respects the results are still inconclusive, but they indicate the need for further work in this field.

\section{SubJeCTS AND MeTHODS}

Finger-prints obtained from 150 patients with congenital heart disease, all of whom have been investigated in the Department of Cardiology of the Institute for Medical Research, form the material for this study. The diagnosis of the cardiac anomaly was determined by a full clinical study and cardiac catheterization in all the cases. In many, anatomical confirmation of the diagnosis at operation or necropsy was available. Cases in which the diagnosis of the type of cardiac anomaly was not well established have not been included.

There were 14 patients with atrial septal defect, 21 with isolated ventricular septal defect, 20 with pure pulmonary valve stenosis, 34 with Fallot's tetralogy, 15 with aortic stenosis (including both valvar and subvalvar), 11 with aortic coarctation, 12 with patent ductus arteriosus, and 23 with various other anomalies mostly transposition but including cases of atrio-ventricularis communis, Ebstein's disease, valve atresia, etc.

Prints were obtained for all five digits of both hands in every subject (i.e. 10 from each patient). The individual finger-prints were classified according to the number and the position of their triradii (Fig. 1), as arches when there was no triradius, as loops when there was one triradius (ulnar loop with triradius in radial position, radial loop with triradius in ulnar position), and as whorls when there were two triradii, ulnar and radial.

\section{RESULTS}

Figure 1 shows the percentage of each type of individual finger-print found in each of the diagnostic groups. For the total series the observed differences are statistically significant with $\chi^{2}=95.905$ and $\mathbf{p}>\mathbf{0 . 0 0 1}$. They were also significant for many of the individual groups.

Arches are present in 5-10 per cent of the prints from the controls and most of the congenital 


\begin{tabular}{|c|c|c|c|c|c|c|c|}
\hline & & ARCHES & $\begin{array}{l}\text { ULNAR } \\
\text { LOOPS }\end{array}$ & $\begin{array}{l}\text { RADIAL } \\
\text { LOOPS }\end{array}$ & WHORLS & $x^{2}$ & $p<$ \\
\hline GROUP & CASES & & (1) & & 101 & 95.905 & 0.001 \\
\hline ASD & 14 & & & & & $2 \cdot 87$ & 0.5 \\
\hline VSD & 21 & & & & & 12.55 & 0.01 \\
\hline PS & 20 & & & & & 34.575 & 0.001 \\
\hline FT & 34 & & & & & 9.24 & 0.05 \\
\hline AS & 15 & & & & & $17 \cdot 12$ & 0.001 \\
\hline$\overline{A C}$ & 11 & & & & & 9.54 & 0.05 \\
\hline PDA & 12 & & & & & $4 \cdot 16$ & 0.3 \\
\hline Vor: & 23 & & & & & 5.55 & 0.2 \\
\hline Nor. & 50 & & & & & $x^{2}$ & $p<$ \\
\hline
\end{tabular}

FIG. 1.-This shows the frequency of the different individual finger-print patterns found in various groups of subjects studied. Abbreviations on the left are as indicated in the text. The different finger-print patterns are illustrated at the top, and from left to right are arches, ulnar loops, radial loops, and whorls. The length of the bars beneath these symbols indicates their incidence in each group. The results of the statistical tests of the significance of the differences observed are given in the right-hand columns.

heart disease groups, but account for as much as 17 per cent in pulmonary valve stenosis and for only 2.5 per cent in aortic coarctation.

Ulnar loops are clearly dominant $(60-70 \%)$ in all the congenital heart groups as well as in the controls; they are specially frequent in ventricular septal defect $(75 \%)$ but less common in aortic stenosis $(49 \%)$, aortic coarctation $(56 \%)$, and Fallot's tetralogy $(57 \%)$.

Radial loops are infrequent, accounting for 3-5 per cent of the prints in controls and most groups of congenital heart disease; they are, however, more frequent in atrial septal defect and the group of various anomalies $(6 \%$ in both) but even less common in pulmonary stenosis and aortic stenosis (less than $2 \%$ in both).

Finally, whorls occurred in 15-30 per cent of finger-prints in the controls and most heart anomalies, but were less frequent in pulmonary stenosis $(14 \%)$ and much more frequent in aortic stenosis $(41 \%)$, aortic coarctation (37\%), and Fallot's tetralogy $(33 \%)$.

The increased incidence of any particular print pattern in a diagnostic group may result from either (i) a greater proportion of patients each with few prints of that pattern, or (ii) the occurrence of a few patients each with a large number of prints of the appropriate pattern.

Similarly, a low incidence of a pattern could be due to either (iii) the group containing very few subjects, each with the normal number of the particular print pattern, the majority having slightly fewer than the normal number, or (iv) a few patients in the group having very much fewer than the normal number of the print pattern.

Table I illustrates this point: it seems that mechanism (i) only was responsible for the increased number of radial loops in atrial septal defect, whereas mechanism (ii) accounted for the increase in the number of arches in pulmonary stenosis, ulnar loops in ventricular septal defect, and whorls in aortic stenosis, aortic coarctation, and Fallot's tetralogy. On the other hand, both mechanism (iii) and (iv) were acting in decreasing the number of radial loops in aortic stenosis and pulmonary stenosis, whereas mechanism (iv) alone accounted for the diminution of arches in aortic coarctation, ulnar loops in aortic stenosis, aortic coarctation, and Fallot's tetralogy, and whorls in pulmonary stenosis. Generally it seems that the differences in the frequencies of the various print patterns in 
TABLE I

Percentage Frequencies of Cases with No, Few, and Many Prints of each Type in the Different Groups of CONGENital Heart Disease

\begin{tabular}{|c|c|c|c|c|c|c|c|c|c|c|c|}
\hline & & $\begin{array}{l}\text { No. of } \\
\text { prints }\end{array}$ & $\begin{array}{l}\text { Atrial } \\
\text { septal } \\
\text { defect }\end{array}$ & $\begin{array}{l}\text { Ventr. } \\
\text { septal } \\
\text { defect }\end{array}$ & $\begin{array}{l}\text { Pulm. } \\
\text { stenosis }\end{array}$ & $\begin{array}{c}\text { Fallot's } \\
\text { tetralogy }\end{array}$ & $\begin{array}{c}\text { Aortic } \\
\text { stenosis }\end{array}$ & $\begin{array}{l}\text { Aortic } \\
\text { coarct. }\end{array}$ & $\begin{array}{l}\text { Patent } \\
\text { ductus } \\
\text { arterio. }\end{array}$ & $\begin{array}{l}\text { Various } \\
\text { others }\end{array}$ & Normal \\
\hline Arches.. & $\ldots$ & $\begin{array}{l}0 \\
1-2 \\
3-10\end{array}$ & $\begin{array}{l}50 \\
50 \\
-\end{array}$ & $\begin{array}{r}75 \\
20 \\
5\end{array}$ & $\begin{array}{l}45 \\
30 \\
25\end{array}$ & $\begin{array}{r}80 \\
15 \\
5\end{array}$ & $\begin{array}{r}80 \\
7 \\
13\end{array}$ & $\begin{array}{l}70 \\
30 \\
-\end{array}$ & $\begin{array}{r}65 \\
27 \\
8\end{array}$ & $\begin{array}{r}76 \\
16 \\
8\end{array}$ & $\begin{array}{r}64 \\
32 \\
4\end{array}$ \\
\hline Ulnar loops & .. & $\begin{array}{l}0 \\
1-4 \\
5-10\end{array}$ & $\begin{array}{l}\overline{22} \\
78\end{array}$ & $\begin{array}{l}\overline{10} \\
90\end{array}$ & $\begin{array}{r}5 \\
15 \\
80\end{array}$ & $\begin{array}{l}12 \\
24 \\
64\end{array}$ & $\begin{array}{l}20 \\
21 \\
59\end{array}$ & $\begin{array}{l}\overline{36} \\
64\end{array}$ & $\overline{\overline{1}}$ & $\begin{array}{l}\overline{22} \\
78\end{array}$ & $\begin{array}{l}\overline{26} \\
74\end{array}$ \\
\hline Radial loops & . & $\begin{array}{l}0 \\
1 \\
2\end{array}$ & $\begin{array}{r}50 \\
43 \\
7\end{array}$ & $\begin{array}{r}70 \\
25 \\
5\end{array}$ & $\begin{array}{l}80 \\
20 \\
-\end{array}$ & $\begin{array}{r}80 \\
17 \\
3\end{array}$ & $\begin{array}{l}80 \\
20 \\
-\end{array}$ & $\begin{array}{r}73 \\
9 \\
18\end{array}$ & $\begin{array}{r}75 \\
17 \\
8\end{array}$ & $\begin{array}{l}70 \\
13 \\
17\end{array}$ & $\begin{array}{r}66 \\
30 \\
4\end{array}$ \\
\hline Whorls & .. & $\begin{array}{l}0 \\
1-4 \\
5-10\end{array}$ & $\begin{array}{r}29 \\
65 \\
6\end{array}$ & $\begin{array}{l}38 \\
52 \\
10\end{array}$ & $\begin{array}{l}40 \\
50 \\
10\end{array}$ & $\begin{array}{l}26 \\
41 \\
33\end{array}$ & $\begin{array}{l}25 \\
41 \\
34\end{array}$ & $\begin{array}{l}18 \\
45 \\
37\end{array}$ & $\begin{array}{r}34 \\
58 \\
8\end{array}$ & $\begin{array}{l}26 \\
48 \\
26\end{array}$ & $\begin{array}{l}28 \\
46 \\
26\end{array}$ \\
\hline
\end{tabular}

the different diagnostic groups are due largely to the presence in each group concerned of a few cases with many prints of certain types.

By analysis of the mean number of fingers having each print pattern and the maximum frequencies of print types on each finger, it has been possible tentatively to ascribe a print formula to each of the different cardiac anomalies. In this way, starting with the right hand and then the left one (fingers 1 to 5), atrial septal defect should have an UAUWU-URUWU formula; ventricular septal defect, WUUWU-UAUUU; pulmonary stenosis, UAUWU-UAUUU; Fallot's tetralogy, UWWWUUAUUU; aortic stenosis, UWUWU-AWUWU; aortic coarctation, UWWWU-UWUUU; and patent ductus arteriosus, UWUWU-UAUUU: by comparison the controls are WAUWAUUUWU.

\section{Discussion}

The analysis of family histories has helped to unravel the interplay between genetic and environmental factors in the causation of congenital heart disease. The role of genetic factors has been supported by the familial aggregation of anomalies and the higher than normal incidence of parental consanguinity (McKusick, 1959). The association of congenital heart malformations with genetically determined syndrome or traits provides further support for the genetic causation of cardiovascular anomalies.

Dermatoglyphic traits, mainly finger and palm prints, have been principally studied in mongolism (Penrose, 1961) and are now being studied in other chromosomal aberrations with positive results (Penrose, 1963).

Hale, Phillips, and Burch (1961) have studied the palm axial triradius $t$ location in 157 patients with congenital heart disease in comparison to 143 with acquired heart disease. They found a clear tendency towards a distal triradius in the former group, with statistically significant differences between the two: they did not study finger-print pattern. Rowe and Uchida (1961) have found that only 24 per cent of mongoloid subjects with heart malformations have a normal position of the palm $t$ triradius compared to 40 per cent of those without heart involvement: again they did not study finger-print differences.

Our results suggest an association between at least a proportion of congenital heart patients and the finger-print patterns. In this series there was a high number of arches in pulmonary stenosis, ulnar loops in ventricular septal defect, radial loops in atrial septal defect, and whorls in aortic 
stenosis, aortic coarctation, and Fallot's tetralogy. The differences are statistically significant. It seems that increased incidence of these finger-print patterns is mainly due to a small number of cases bearing many such prints. This suggests that these few individuals may represent the fraction of the patients in each group whose heart lesion is genetically determined.

These observations may also have a practical value in diagnosis: a congenital cardiac anomaly associated with more than two arches is very likely to be pulmonary stenosis; and a case with more than four whorls has probably either aortic stenosis, aortic coarctation, or Fallot's tetralogy. Differential diagnosis between cyanotic pulmonary stenosis and Fallot's tetralogy, or between acyanotic Fallot's tetralogy and isolated ventricular septal defect would be practical examples of the utility of these findings.

As previously stated this is a preliminary report and further work remains to be done. The number of patients in each of the groups of congenital heart anomalies in this series needs to be amplified and the last group (various anomalies) has to be subdivided in order to analyse the individual pattern of those rarer anomalies. Furthermore the findings already raise a number of other questions. (i) The comparison of those cases identified by their dermatoglyphic pattern with the rest of the patients with congenital heart disease with respect to their family histories-frequency of association with non-cardiac anomalies, etc. (ii) Dermatoglyphic analysis of the relatives of the patients to find either a tendency towards the same print pattern in them, suggesting a familial trait, or contrariwise, a family discordance in finger-print patterns, suggesting a mutation as the cause of both fingerprint and heart anomaly. (iii) Testing differences in the frequency of the various print patterns in each finger in a larger series.

\section{SUMMARY}

The finger-prints from 150 cases of congenital heart disease have been analysed and compared with those from 50 control subjects. The total differences in print pattern were statistically significant. Arches were very frequent in pulmonary stenosis and extremely rare in aortic coarctation. Ulnar loops were the most frequent type in all groups, and there were even more in ventricular septal defect. Radial loops were very rare in general, but a little more frequent in atrial septal defect. Whorls were frequent in aortic stenosis, aortic coarctation, and Fallot's tetralogy.

The association between different finger-print patterns and certain forms of congenital heart disease lends support to the view that a proportion, at least, of the cardiovascular anomalies are genetically determined. These preliminary observations indicate the need for further studies in this field.

I am indebted to Dr. Dennis Deuchar, of Guy's Hospital, London, for his kind help in the preparation of this paper.

\section{REFERENCES}

Hale, A. R., Phillips, J. H., and Burch, G. E. (1961). Features of palmar dermatoglyphics in congenital heart disease: a report on the variants frequently associated with congenital lesions of the heart. J. Amer. med. Ass., $176,41$.

McKusick, V. A. (1959). Genetic factors in cardiovascular disease: I. The four major types of cardiovascular disease. Mod. Conc. cardiovasc. Dis., 28, 535.

Penrose, L. S. (1961). Mongolism. Brit. med. Bull., 17, 184.

- (1963). Finger-prints, palms and chromosomes. Nature (Lond.), 197, 933.

Rowe, R. D., and Uchida, I. A. (1961). Cardiac malformation in mongolism: A prospective study of 184 mongoloid children. Amer. J. Med., 31, 726. 